\title{
Understanding the internet banking adoption factors in the Romanian market
}

\author{
Mihaela-Rodica GANCIU \\ Energomontaj S.A., Bucharest, Romania \\ Mihaella.Ganciu@Gmail.Com \\ Ramona-Alexandra NEGHINĂ \\ Webecom S.R.L., Bucharest, Romania \\ Ramona@Webecom.Ro \\ Valentin-Andrei MĂNESCU \\ Webecom S.R.L., Bucharest, Romania \\ Mail@Valentinmanescu.Ro \\ Petronela-Cristina SIMION \\ University Politehnica of Bucharest, Bucharest, Romania \\ Petronela.Simion@Upb.Ro \\ Gheorghe MILITARU \\ University Politehnica of Bucharest, Bucharest, Romania \\ Gheorghe.Militaru@Upb.Ro
}

\begin{abstract}
Online banking services create a way to reduce costs, attracting new segments of population and growing the bank performance and improvement of services. Client's satisfaction is the main benefits of the banks. The aim of the paper is to investigate and to analyze the factors that influence the adoption of internet banking system in Romania. One of the problems faced by consumers using Internet banking is confidentiality. This makes security in transactions to be essential. For this, the main objectives are: identifying critical factors that contribute to the acceptance of internet banking system and the link between them and also identifying the demographic factors that influence the adoption of this system in Romania. The data collection was done by a quantitative research using the questionnaire method as a survey tool and it was made up of questions measured using the Likert scale. It contains variables based on the construct's relevance to Internet Banking. All assumptions about the relationship between dependent variables and independent variables are developed and tested using multiple reliability, validity, and regression. It was used a statistical software and with it were analised 6 independent variables, named social influence, perceived ease of use, perceived usefulness, perceived risk, perceived confidence and intention to use Internet banking. The attitude toward using Internet banking system will be the dependent variable. To verify the acceptability model's validity, it was used the Structural Equations Model. The results are partly supported by the developed hypotheses and are presented after the reliability test where Cronbach's Alpha is calculated suggesting the internal reliability of the consistency for the scale. The significant effect that influences the attitude toward using Internet banking system is represented by the perceived usefulness, the perceived risk, the perceived confidence and the intention to use internet banking.
\end{abstract}

Keywords: online internet banking, e-banking acceptance research, digital transactions, technology acceptance model, internet banking in Romania. 


\section{Introduction}

Banks are important links in an economy as they have a significant role in maintaining and encouraging the development of the economic sectors. It is useful to bring to the fore the IT\&C technology available today by most banks. In the last few decades, Internet technology has grown more and more, reaching today's entire business environment. On the Internet there are almost all types of activities that are executed daily by employees in bank branches.

Currently the world is witnessing a migration of activities to the online environment, but this does not mean the disappearance of the usual economic activities. The main objective of this study was to find out if there are significant associations in the adoption of internet banking services between users and their friends. Secondly, this second study was also interested in identifying which of the constructs investigated so far are susceptible to such associations.

The paper aims to answer the questions "What impact does the technology have on banking performance? Is there a real benefit for consumers in terms of using this payment system? What are the critical factors that influence the adoption of the Internet banking payment system?"

The main advantages of internet banking are the effective reduction of the time for banking transactions, their costs, their easement, and above all, the attraction of new customers leading to a bigger part of a company's business.

\section{Literature review and hypotheses \\ Internet - Banking Concept}

It is important to note that the banks have invested in expanding their investment and lending to the banks. Otherwise, they are aware that they have been forced to deliver their services through a mud called intranet. By the introduction of the Internet in 1969, it was the sole responsibility of the computer and the computer to be a basic principle of communication.

Internet Banking: It is also known as Web Banking, PC-Banking or e-Banking. Easier accessibility to internet facility and availability of computer determine banks to provide its products and services through a new way of delivery, through internet (Georgescu-Golosoiu, 2003). Even if internet banking save time and money, it offers confort and acessibility and it has a positive impact concerning clients satisfaction (Thornton \& White, 2001. The use of Internet banking has grown rapidly over the last decade, a long side the Internet. This has led to major changes in the functioning of banks, when the Internet has grown - and the number of services provided by banks (Chechen et al., 2016). The challenges facing today's industry are developing software more recently and faster, while struggling with maintaining security. The success of these new services is not only determined by the bank, but rather than acceptance by users (Oruca \& Tatar, 2017). Of the bank's payment system benefit not only the clients, but also the bank itself. Online banking services create a way to reduce costs, attracting new segments of population and growing the bank performance and improvement of services. Client's satisfaction are the main benefits of the banks. Online Banking services create a way to reduce documents and human errors, which minimize disagreements, in addition to reducing commissions (Kiang et al., 2000).

Due to the quick changes in the information technology, banks are faced with specific risks associated with electronic bank and electronic coin activities. At this level, it seems that 
operational risk, reputational and legal risks are the most important categories of risks, especially for international banks (Georgescu-Golosoiu, 2003). Online banking services offer a full range of services, including some services that are not offered in the physical branches. The greatest benefit of the online banking services it is the fact that is cheap or even free for costumers. This thing allows to costumers to be more loyal to the electronic bank that the traditional bank customers (Mols, 1998).

PICBE $\mid 349$

Today's customers are demanding much more the online banking services. They are searching for new levels of comfort and flexibility, besides strong and easy-to-use financial management tools and products and services that the traditional retail bank could not offer (Birch \& Young, 1997).

\section{Technology Acceptance Model}

The Technology Acceptance Model was proposed by Fred D. Davis in 1986 in his doctoral thesis, an adaptation of TRA (Theory of reasoned action). The model was developed to explain the use of new technologies by adopting a causal relationship between beliefs, perceptions, attitudes, intentions and behavior. The major constructs in Davis's TAM are perceived usefulness ("the degree to which a person believes that using a particular system leads to increased performance of his activities in an organizational context") and ease of use (the "degree that the use of a particular system is effortless") (Davis, 1989).

Even if TAM Model was introduced for the first time in 1989, it is still widely used. In spite of all this, many studies state that TAM is inadequate to explain users' decisions to adopt technology, so they use TAM as the basic model and extended the model by adding more variables by sucking the innovation theory, depending on the types studied technologies (Jeyaraj et al., 2006).

At present, the most important models of technology acceptance (TAMs) are models developed by Venkatesh et al. (2003), based on the Unified Theory of Technology Acceptance and Use (Venkatesh et al., 2003) and by Lowry et al. (2012), The Hedonic Motivation Model of Systems Adoption (Lowry et al., 2012). Both models have been updated to the latest versions in 2010 and both incorporate most of the relevant theories in the industry. Also, both models attempt to explain and predict the intention of users to accept, and ultimately, to use technology systems, ie technology acceptance (TA).

Regarding internet banking, older segments are even more attentive than usual, which, according to Nerme, Stenström, Darefelt and Søilen (2013), is due to the fact that it is new and unfamiliar. Thus, it is important for banks to study how quickly different segments adopt new technologies and innovations. These findings indicate that different segments need different information and targeting needs to be customized for each segment to ensure efficiency (Nerme et al., 2013).

The main difference between the two models is at the level of fundamental assumptions. For example, the unified theory of acceptance and use of technologies (UTAUT) is representative of so-called utility models, which stipulate that the main influential factor in the adoption of technologies is the utility of the system or their value related to productivity. Furthermore, from a historical perspective, the study of technology acceptance has started from investigative approaches to the adoption of production systems, such as systems used in logistics, accounting, etc. Lee, Tsai and Lanting (2011) made a comparison between TAM and consumer adoption of online banking services and found a correlation. 
Their study confirmed that if users perceive Internet banking as useful and easy to use, they are more likely to use the service (Lee et al., 2011). Accepting this model offers more benefits, the most important being the creation of a global tool that measures the different perceptions in the adoption of Internet-based technologies (Yee-Loong Chong et al., 2010). As Hartwick $\&$ Barki found, even when users perceive the use of the system as organizational, intentions of use vary because some users are not willing to observe such mandates (Hartwick \& Barki, 1994).

Hypothesis 1: Social influence is positively correlated with the intention to use online banking services

Hypothesis 2: Perceived ease of use of Internet Banking is positively correlated with perceived usefulness and attitude towards using system

Hypothesis 3: The perceived usefulness of the Internet is positively correlated with attitude towards using the system and with intention to use

Hypothesis 4: Attitude towards using the system positively influences the intention to use online banking services

Hypothesis 5: The intention to use is positively correlated with the perceived usefulness of the Internet Banking system

Hypothesis 6: The perceived confidence will positively influence the attitude towards using the system

Hypothesis 7: Perceived risk has a negative impact on attitudes towards using online banking services (Yee-Loong Chong et al., 2010)

\section{Methodology}

The methodological part presents an individual model for the construction of the individual decision in the financial-banking field, which is tested on a sample of respondents over the age of 18. The data collection was done in almost five months, using the questionnaire method, which had 25 questions, and at the end of the session to complete the questionnaire, a total of 150 respondents were registered.

For the dissemination of the measurement tool, a web-based questionnaire developed using Google Forms was used. The link to the final questionnaire was disseminated to respondents via online social networks, such as Facebook/Linkedin, and by email. The first participants were students from the Faculty of Entrepreneurship, Engineering and Business Management. Subsequently, students were asked to disseminate the questionnaire link to their knowledge / friends and their families if they wanted to do so.

The construction of the questionnaire was conducted in such a way that the statements validated by other studies conducted internationally, but adapted to the economic and social environment in Romania, could result in the financial experience, the 
influence of the behavioral factors, the confidence in their own decisions and the confidence of the Romanian individuals in the banks. For this, questions were grouped on these chapters, but randomly placed in the questionnaire.

The questionnaire is a list of statements of various forms that are written in order to collect information relative to a subject. The drafting of the questionnaire is a difficult issue, especially in the case of market studies, because there is no single formulation to produce a very good questionnaire. The Polling Tool contains variables based on the relevance of the construct to Internet Banking (Table 1). From this theory results a set of hypotheses that was expressed in the research. It was measured each construct to maintain the instrument's responsibility and used the Likert scale of points that ranged from "Total Disagreement" to "Total Agreement" as variants of response. Scoring scales typically ask the respondent to select the answer from a series of statements or verbal numbers. Variables that use verbal instructions include semantic differential scales and Likert scale (Dawes, 2008). Likert's scale, also called a summed scale, although it is only an orderly scale, is widely used in marketing research. This scale assumes the use of a set of affirmative or unfavorable statements about the object or phenomenon investigated. For the other questions, were used two other types of scales, namely the Proportional Scale and the Dichotomic Scale.

Table 1. The variables used for the construction of the questionnaire

\begin{tabular}{|c|c|c|c|}
\hline Factor & Variable & Question & Item \\
\hline \multirow{2}{*}{$\begin{array}{l}\text { Social } \\
\text { Influence }\end{array}$} & SI1 & Q4 & $\begin{array}{l}\text { People around me who use Internet banking have more prestige } \\
\text { than those who do not use this system. }\end{array}$ \\
\hline & SI2 & Q5 & The people around me who use this system have a higher status. \\
\hline \multirow{5}{*}{$\begin{array}{l}\text { Perceived } \\
\text { Ease of Use }\end{array}$} & PEU1 & Q6 & $\begin{array}{l}\text { Interaction with the Internet banking system requires mental } \\
\text { effort. }\end{array}$ \\
\hline & PEU2 & Q7 & $\begin{array}{l}\text { I appreciate the application being easy to use for what I want to } \\
\text { do. }\end{array}$ \\
\hline & PEU3 & Q8 & I think Internet Banking is flexible to interact with. \\
\hline & PEU4 & Q9 & I think Internet Banking is easy to use. \\
\hline & PEU5 & Q10 & $\begin{array}{l}\text { I find it easy to get what I need from the Internet Banking } \\
\text { system. }\end{array}$ \\
\hline \multirow{5}{*}{$\begin{array}{l}\text { The Perceived } \\
\text { Usefulness }\end{array}$} & PU1 & Q11 & $\begin{array}{l}\text { Using Internet Banking can make it easier for you to perform } \\
\text { tasks faster. }\end{array}$ \\
\hline & PU2 & Q12 & Using Internet Banking can facilitate my tasks. \\
\hline & PU3 & Q13 & $\begin{array}{l}\text { Using the Internet Banking system can help you consult and / or } \\
\text { make bank transactions. }\end{array}$ \\
\hline & PU4 & Q14 & $\begin{array}{l}\text { Using the mobile app has increased my effectiveness in advising } \\
\text { and / or performing my bank transactions. }\end{array}$ \\
\hline & PU5 & Q15 & I think Internet Banking is useful in my work. \\
\hline \multirow{2}{*}{$\begin{array}{l}\text { Attitude } \\
\text { towards Using } \\
\text { System }\end{array}$} & AU1 & Q16 & I like to use the Internet Banking system. \\
\hline & AU2 & Q17 & $\begin{array}{l}\text { Using the mobile app for queries and / or banking is an effective } \\
\text { method. }\end{array}$ \\
\hline \multirow{3}{*}{$\begin{array}{l}\text { Intention to } \\
\text { Use }\end{array}$} & IU1 & Q18 & $\begin{array}{l}\text { I try to use Internet Banking in as many cases / occasions as } \\
\text { possible. }\end{array}$ \\
\hline & IU2 & Q19 & I intend to continue using Internet Banking in the future. \\
\hline & IU3 & Q20 & Assuming you have access to the mobile app, you plan to use it. \\
\hline $\begin{array}{l}\text { Perceived } \\
\text { Confidence }\end{array}$ & PC1 & Q21 & $\begin{array}{l}\text { I think the internet banking system will maintain the terms and } \\
\text { commitments assumed in relation to the mobile application. }\end{array}$ \\
\hline
\end{tabular}




\begin{tabular}{|l|c|c|l|}
\hline Factor & Variable & Question & \multicolumn{1}{c|}{ Item } \\
\hline & PC2 & Q22 & I think the mobile internet banking application is reliable. \\
\cline { 2 - 4 } & PC3 & Q23 & Generally, I trust the internet banking application. \\
\hline \multirow{3}{*}{$\begin{array}{l}\text { Perceived } \\
\text { Risk }\end{array}$} & PR1 & Q24 & $\begin{array}{l}\text { Others might know about my online transactions if I use this } \\
\text { app. }\end{array}$ \\
\cline { 2 - 5 } & PR2 & Q25 & $\begin{array}{l}\text { There is a significant risk when making banking transactions } \\
\text { through the mobile internet banking application. }\end{array}$ \\
\cline { 2 - 5 } & PR3 & Q26 & $\begin{array}{l}\text { I think doing queries and / or bank transactions withthis app is } \\
\text { a risky choice. }\end{array}$ \\
\hline
\end{tabular}

Source: (Gardner\&Amoroso, 2004), (Lee, 2009) and (Lai\&Li, 2005)

\section{Results and discussions}

This study uses several regressions and correlation analyzes using the statistical program IBM SPSS Statistics. The reason for using the multiple regression tests is to investigate the relationship between independent variables and dependent variables. There are 6 independent variables, namely social influence, perceived ease of use, perceived usefulness, perceived risk, perceived confidence and intention to use internet banking services. The attitude towards using the internet banking system will be the dependent variable. However, correlation analysis was performed to examine the relationship between the variables. The value of the correlation coefficient $(\mathrm{r})$ is between 0.10 and 0.29 , a variable considered to be mild, from 0.30 to 0.49 o variable considered to be average and from 0.50 to 1.0 a variable considered strong. The results of the research are presented after the reliability test if Cronbach's Alpha is calculated suggesting the internal reliability of the consistency for the scale with this sample. The predictive capacity of these variables, all facets of adoption behavior was measured using multiple regressions.

The demographic profile (shown in Table 2) shows a population quite young and well educated, $82.5 \%$ of respondents were under the age of forty years, while $62.0 \%$ of them have at least university. The majority of respondents are female, which is $65.3 \%$, while men are the other respondents $(34.7 \%)$.

Table 2. Demographic profile of respondents

\begin{tabular}{|c|c|c|c|}
\hline \multirow{3}{*}{ Gender } & Attributes & Frequency & Percentage (\%) \\
\hline \multirow{4}{*}{ Age } & Male & 52 & 34.7 \\
\cline { 2 - 4 } & Female & 98 & 65.3 \\
\hline \multirow{3}{*}{ Level of education } & $21-30$ years & 133 & 53.3 \\
\cline { 2 - 4 } & $31-40$ years & 10 & 29.2 \\
\cline { 2 - 4 } & 41-50 years & 7 & 14.2 \\
\cline { 2 - 4 } & 51-60 years & 0 & 3.3 \\
\cline { 2 - 4 } & University studies & 93 & 62.0 \\
\cline { 2 - 4 } & Postgraduate studies & 41 & 27.3 \\
\hline & Other & 16 & 10.7 \\
\hline
\end{tabular}

Source: Authors' own research

On the reliability test, the Cronbach Alpha values were calculated to evaluate the internal reliability of scale consistency. According to Table 3, the value of the correlation coefficient for the 18 variables structured in 7 factors in this study ranged from 0.232 to 0.502. The Cronbach Alpha coefficient is used to study the internal consistency of the items in a questionnaire, or it can be used as a method to reduce items. In this case, the Cronbach 
Alpha value is 0.744 , indicating an acceptable value for good. Furthermore, it indicates a high degree of internal consistency with regard to the specific sample.

Throw the test of validity, it was improved Alpha coefficient. It was reduced the analysis of the 23 variables to an analysis of 18 variables, removing 5 of them by analyzing the correlation coefficient. Performing these operations, I obtained a value of 0.744 for the Alpha coefficient (seen in Table 4). Given that some of the correlated values of the elements are not very low ( $>200)$, their removal from the general questionnaire will not be considered.

The graph is useful for determining the number of factors to be retained (see Figure 1). The point of interest is where the curve begins to flatten. It can be seen this aspect between factors 8 and 9, and because of this fact, seven (7) factors are selected to rotate.

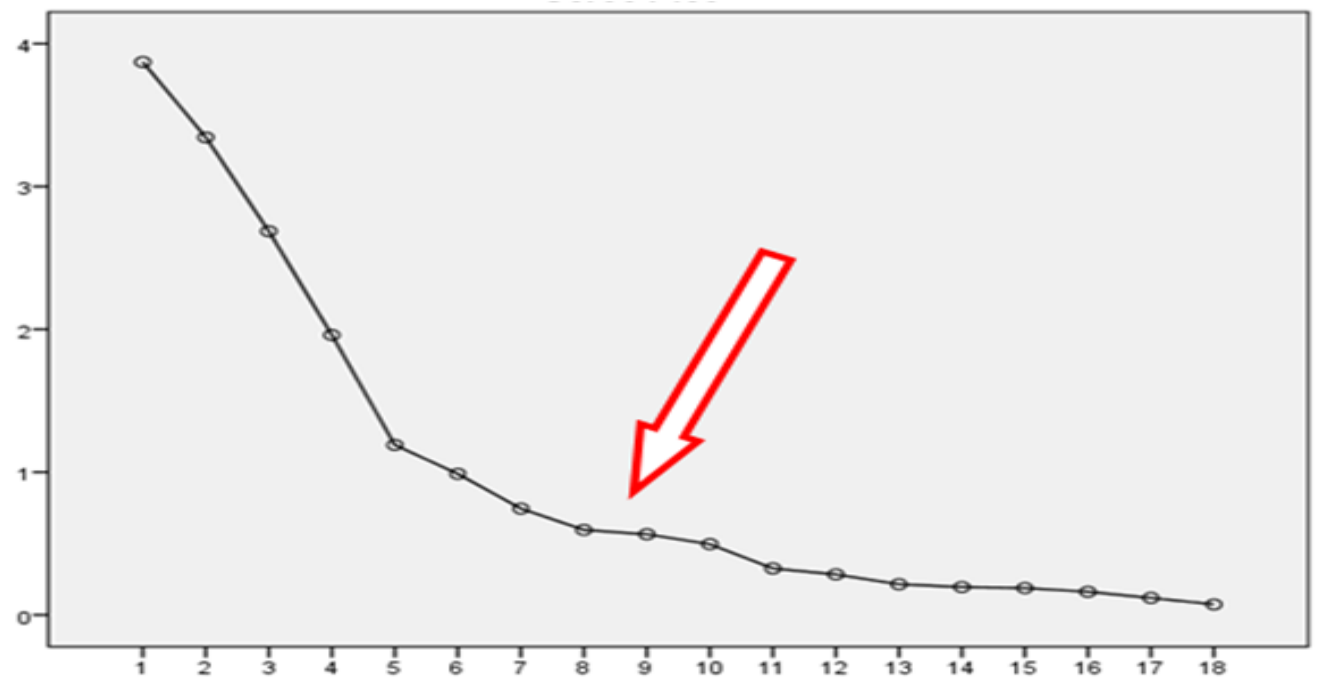

Figure 1. Determination of the number of factors to be retained

Source: Authors' own research.

Table 3. Validity test-Correlation coefficient factors

\begin{tabular}{|c|c|c|c|c|}
\hline & $\begin{array}{l}\text { Scale Mean if } \\
\text { Item Deleted }\end{array}$ & $\begin{array}{l}\text { Scale Variance } \\
\text { if Item Deleted }\end{array}$ & $\begin{array}{c}\text { Corrected } \\
\text { Item-Total } \\
\text { Correlation }\end{array}$ & $\begin{array}{l}\text { Cronbach's Alpha } \\
\text { if Item Deleted }\end{array}$ \\
\hline \multicolumn{5}{|c|}{ Social Influence } \\
\hline SI1 & 96.4333 & 148.180 & .335 & .733 \\
\hline SI2 & 96.3333 & 145.512 & .412 & .724 \\
\hline \multicolumn{5}{|c|}{ Perceived Ease of Use } \\
\hline PEU1 & 95.4067 & 161.438 & .266 & .738 \\
\hline PEU2 & 95.5800 & 162.030 & .254 & .739 \\
\hline PEU3 & 95.7267 & 160.119 & .280 & .737 \\
\hline \multicolumn{5}{|c|}{ Perceived Usefulness } \\
\hline PU1 & 96.0333 & 155.147 & .256 & .740 \\
\hline PU2 & 96.3467 & 154.470 & .232 & .743 \\
\hline PU3 & 95.7533 & 154.724 & .427 & .727 \\
\hline \multicolumn{5}{|c|}{ Attitude towards Using System } \\
\hline AU1 & 95.5400 & 159.391 & .327 & .734 \\
\hline AU2 & 95.6267 & 161.027 & .240 & .739 \\
\hline
\end{tabular}




\begin{tabular}{|c|c|c|c|c|}
\hline & $\begin{array}{l}\text { Scale Mean if } \\
\text { Item Deleted }\end{array}$ & $\begin{array}{l}\text { Scale Variance } \\
\text { if Item Deleted }\end{array}$ & $\begin{array}{c}\text { Corrected } \\
\text { Item-Total } \\
\text { Correlation } \\
\end{array}$ & $\begin{array}{l}\text { Cronbach's Alpha } \\
\text { if Item Deleted }\end{array}$ \\
\hline \multicolumn{5}{|c|}{ Intention to Use } \\
\hline IU1 & 95.5400 & 153.700 & .376 & .729 \\
\hline IU2 & 95.4467 & 160.128 & .343 & .734 \\
\hline \multicolumn{5}{|c|}{ Perceived Confidence } \\
\hline PC1 & 96.0867 & 157.247 & 239 & .740 \\
\hline PC2 & 95.5133 & 161.325 & .324 & .735 \\
\hline PC3 & 95.7000 & 161.366 & .271 & .738 \\
\hline \multicolumn{5}{|c|}{ Perceived Risk } \\
\hline PR1 & 97.4000 & 149.074 & .310 & .736 \\
\hline PR2 & 97.7467 & 138.003 & .490 & .715 \\
\hline PR3 & 98.1600 & 137.142 & .502 & .713 \\
\hline
\end{tabular}

Source: Authors' own research.

Table 4. Reliability statistics - Cronbach Alpha

\begin{tabular}{|c|c|c|}
\hline Cronbach's Alpha & $\begin{array}{c}\text { Cronbach's Alpha } \\
\text { Based on Standardized } \\
\text { Items }\end{array}$ & N of Items \\
\hline .744 & .764 & 18 \\
\hline
\end{tabular}

Source: Authors' own research.

Finally, the Rotated Components Matrix (see Table 5) shows the factor loads for each variable. I went over each row and highlighted the factor that each variable loaded strongly.Based on these factors loads, the factors are: Factor 1 - Attitude towards using system, Factor 2 - Perceived Ease of Use, Factor 3 - Perceived Risk, Factor 4 - Perceived Usefulness, Factor 5 - Social Influence, Factor 6 - Intention to Use and Factor 7 - Perceived Confidence.Table 5. Rotated Components Matrix

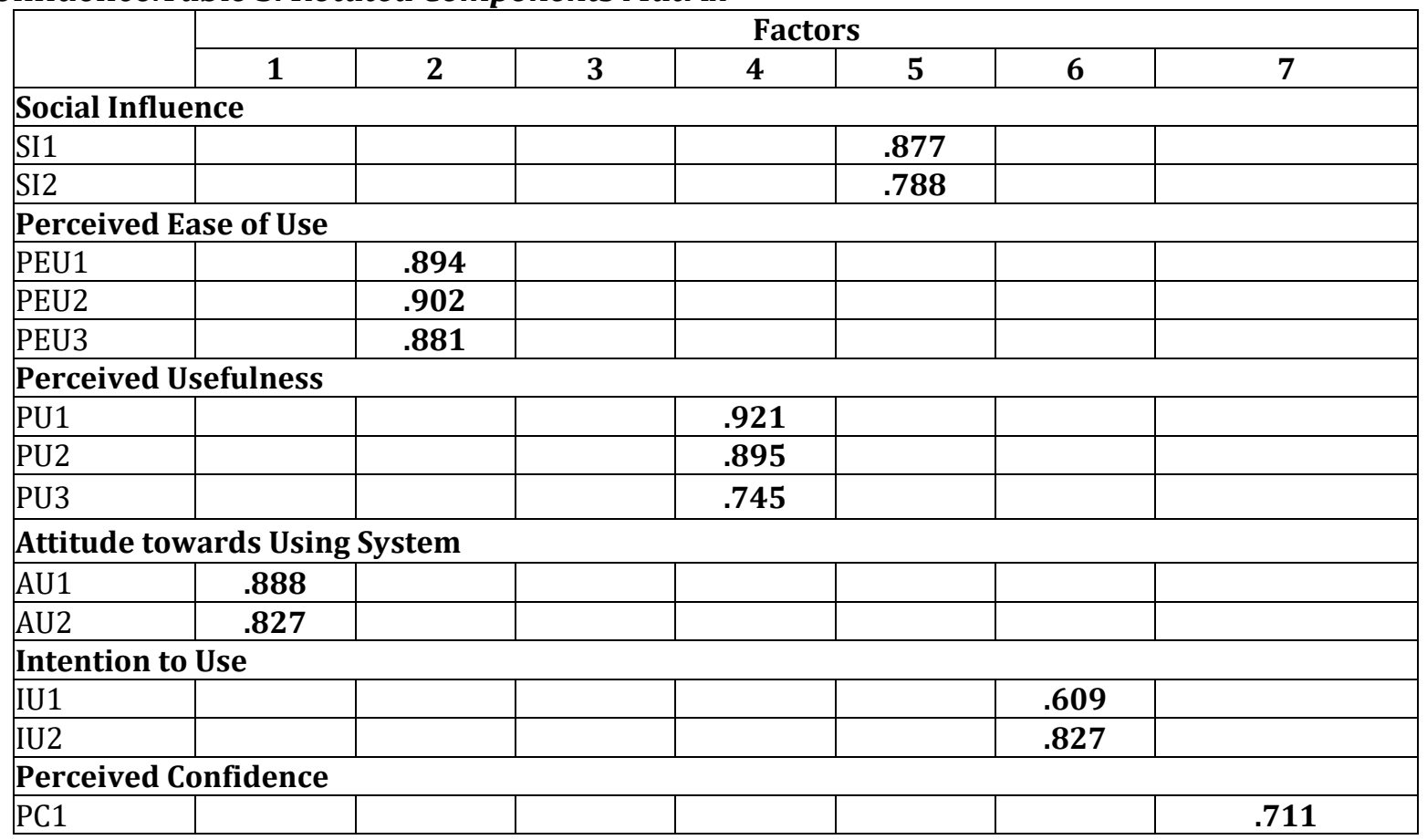

DOI: $10.2478 /$ picbe-2019-0031, pp. 347-360, ISSN 2558-9652| Proceedings of the $13^{\text {th }}$ International Conference on Business 


\begin{tabular}{|c|c|c|c|c|c|c|c|}
\hline & \multicolumn{7}{|c|}{ Factors } \\
\hline & 1 & 2 & 3 & 4 & 5 & 6 & 7 \\
\hline $\mathrm{PC} 2$ & & & & & & & .365 \\
\hline PC3 & & & & & & & .861 \\
\hline \multicolumn{8}{|c|}{ Perceived Risk } \\
\hline PR1 & & & .843 & & & & \\
\hline PR2 & & & .899 & & & & \\
\hline PR3 & & & .868 & & & & \\
\hline
\end{tabular}

Extraction Method: Principal Component Analysis. Rotation Method: Varimax with Kaiser Normalization. a. Rotation converged in 7 iterations.

Source: Authors' own research.

Using the Multiple Regression Test, Table 6 shows a significant pattern of regression between Social Influence, Perceived Ease of Use, Perceived Use, Intention to Use, Perceived Confidence and Perceived Risk. As we can see, the power of each predictive variable, suggesting the dominance of the largest ones, is the scale of intent to use $(t=7.368)$, the perceived usefulness scale $(t=2.082)$, the scale of perceived confidence $(t=.955)$ and perceived risk scale $(t=-1.143)$. The value of the $R^{2}$ effect value identifies the portion of the variation represented by the independent variables, so about $62 \%$ of the Attitude towards Using the System is represented by Social Influence, Perceived Ease of Use, Perceived Usefulness, Intention to Use, Perceived Confidence and Perceived Risk. To verify the validity of the model, it was used the Structural Equations Model using the IBM SPSS AMOS program (see Figure 2). The verification of the hypotheses studied is presented in Table 7. 




PICBE | 356

Figure 2.The TAM model on the acceptance of the Internet-Banking system

Source: Authors' own research.

Table 6. Multiple regression tests

\begin{tabular}{|l|c|c|c|c|}
\hline & Attitude towards Using System & \multicolumn{2}{c|}{ Significance } \\
\hline Variables & $B$ & $\beta$ & $t$ & Sig (p) \\
\hline Constant & 1.454 & & 1.766 & .080 \\
\hline Social Influence & -.023 & -.038 & -.495 & .622 \\
\hline Perceived Ease of Use & -.050 & -.038 & -.550 & .583 \\
\hline Perceived Usefulness & .127 & .154 & 2.082 & .039 \\
\hline Intention to Use & .664 & .547 & 7.368 & .000 \\
\hline Perceived Confidence & .096 & .077 & .995 & .321 \\
\hline Perceived Risk & -.044 & -.079 & -1.143 & .255 \\
\hline $\mathrm{R}^{2}=.619(61.9 \%)$ & & & \\
\hline
\end{tabular}

Source: Authors' own research. 
Table 7. Verifying the hypotheses studied

\begin{tabular}{|l|c|c|c|}
\hline \multicolumn{1}{|c|}{ Hypothesis } & Coefficient $\boldsymbol{\beta}$ & Error & $\begin{array}{c}\text { Validation / } \\
\text { Invalidation of } \\
\text { Hypothesis }\end{array}$ \\
\hline $\begin{array}{l}\text { H1: Social influence is positively correlated with } \\
\text { the intention to use online banking services }\end{array}$ & .025 & .182 & VALIDATE \\
\hline $\begin{array}{l}\text { H2: Perceived ease of use of Internet Banking is } \\
\text { positively correlated with perceived usefulness } \\
\text { and attitude towards using system }\end{array}$ & -.014 & .110 & INVALIDATE \\
\hline $\begin{array}{l}\text { H3: The perceived usefulness of the Internet is } \\
\text { positively correlated with attitude towards the } \\
\text { use of the system and with intention to use }\end{array}$ & .172 & .054 & VALIDATE \\
\hline $\begin{array}{l}\text { H4: Attitude towards using system positively } \\
\text { influence the intention to use online banking } \\
\text { services }\end{array}$ & .655 & .054 & VALIDATE \\
\hline $\begin{array}{l}\text { H5: The intention to use is positively correlated } \\
\text { with the perceived usefulness of Internet } \\
\text { Banking }\end{array}$ & .582 & .136 & VALIDATE \\
\hline $\begin{array}{l}\text { H6: The perceived confidence will positively } \\
\text { influence the attitude towards using the system }\end{array}$ & .101 & .064 & VALIDATE \\
\hline $\begin{array}{l}\text { H7: Perceived risk has a negative impact on } \\
\text { attitude towards using the internet banking } \\
\text { system }\end{array}$ & -.116 & .028 & VALIDATE \\
\hline
\end{tabular}

PICBE | 357

Source: Authors' own research.

Following the completion of the study, the following hypotheses were validated:H1: Social influence is positively correlated with the intention to use online banking services, H3: The perceived usefulness of the Internet is positively correlated with attitude towards the use of the system and with intention to use, H4: Attitude towards use positively influence the intention to use online banking services, H5: The intention to use is positively correlated with the perceived usefulness of Internet Banking, H6: The perceived confidence will positively influence the attitude towards using the system and H7: Perceived risk has a negative impact on attitude towards using the internet banking system.

H2: Perceived ease of use of internet banking is positively corresponding to attitude to using the system was not validated. The young generation is much more intelligent when compared to the elderly generation and their attitude to adopt the online bank. Generally, when it is found that a system is easy to use, users will intend to use the system. This factor is defined as the extent to which the use of Internet banking by customers is perceived as mild or effortless. Although the current young generation is more intelligent and more open to new technologies, they also have a certain degree of skepticism about electronic banking transactions due to the associated risks. Analyzing the result, the ease of perceived use does not have a significant negative influence, which is to some extent demonstrated by the above. It can be said that not all people are useful in this way, but prefer to move to a bank's branch for safety. 


\section{Conclusion}

The study on the implementation of the Internet - Banking payment system was based on the analysis of the factors of the Technology Acceptance Model (TAM), using the SPSS statistical program. The need for this research was essentially connected to extremely rapid impact of the technology on human life and increasing the digital bank's interactions and their role in human life.

This model is based on the analysis of constructs, their fundamental theory, and the relationships between these constructs that are related to Internet Banking applications. This tool, which includes all original TAM constructions (including attitudes towards use), can now be used to investigate how consumers adopt and accept applications based on Internet Banking. The development process has also helped to clarify and refine definitions used by a variety of researchers using the technology acceptance model.

Each construct was measured to maintain the instrument's responsibility and was used the seven-point Likert scale ranging from "Total Disagreement" to "Total Agreement" as variants of response. To measure the existing tools, I chose the appropriate items, reviewed the elements, and made a development process. The tool includes TAM constructions and additional variables that can be used to investigate how consumers are adopting Internet Banking applications.

The significant effect that influences the attitude in the use of on-line banking services is the perceived usefulness, perceived risk, the perceived confidence and the intention to use internet banking services. If this service grows as high as possible, then these services can be deployed with the final customer choice. The measure of Internet quality is reflected by the degree of usability of the online system. For individuals, the Internet banking system is based on payment cards, which have a high security system, and legal entities use Internet banking based on transactions in accounts. This is an exploratory research and it was done to identify the adoption rate of internet banking systems. The research is relevant to understand the sample respondents' experience but is not representative for the population that is using internet banking solutions. It doesn't specifically address the types of devices used (for example, mobile vs. desktop), and can be a key element in the adoption of these banking solutions. The variables obtained from the questions in the questionnaire represent the stated perception of the respondents, not necessarily what they think, being a problem frequently encountered. Research could not include analysis before using the application and after the user uses it, to see if there is a cognitive dissonance phenomenon.

In addition, this topic has never been studied in Romania nor the topic of internet banking adoption, despite its importance and timeliness, nor the models of technology acceptance have been investigated so deeply and thoroughly in the Romanian socio-cultural context. Studies of electronic payment systems adoption were realized in many developed and western countries. Thus, this study has tried to investigate factors that can influence the acceptance of online banking services by costumers in Romania. 


\section{References}

Birch, D., \& Young, M. (1997). Financiar services and the Internet - what does cyberspace mean for the financial services industry? Internet Research, 7(2), 120-128. doi:10.1108/10662249710165262

Chechen, L., Huang, Y.-J., \& Tung-Heng, H. (2016). Social behavior and personality: an international journal. Scientific Journal Publishers, 44(9), 1443-1455. doi:10.2224/sbp.2016.44.9.1443

Davis, F. (1989). Perceived usefulness, perceived ease of use, and user acceptance of information technology. MIS Quarterly, 13(3), 319-340. doi:10.2307/249008

Dawes, J. (2008). Do data characteristics change according to the number of scale points used? An experiment using 5-point, 7-point and 10-point scales. International Journal of Market Research, 50(1), 61-104. doi:10.1177/147078530805000106

Gardner, C., \& Amoroso, D. (2004). Development of an instrument to measure the acceptance of Internet technology by consumers. 37th Annual Hawaii International Conference on System Sciences. Proocedings of the. doi:10.1109/HICSS.2004.1265623

Georgescu-Golosoiu, L. (2003). Mijloace, modalitati si instrumente de plata. Bucharest: ASE. Hartwick, J., \& Barki, H. (1994). Explaining the role of user participation in information system use. Management Science, 40(4), 440-465. doi:10.1287/mnsc.40.4.440

Jeyaraj, A., Rottman, J., \& Lacity, M. (2006). A review of the predictors, linkages, and biases in IT innovation adoption research. Journal of Information Technology, 21(1), 1-23. doi:10.1057/palgrave.jit.2000056

Kiang, M., Raghu, T., \& Shang, K. (2000). Marketing on the Internet - who can benefit from an online marketing approach? Decision Support Systems, 27(4), 383-393. doi:10.1016/s0167-9236(99)00062-7

Lai, V., \& Li, H. (2005). Technology acceptance model for internet banking: an invariance analysis. Information \& Management, 42(2), 373-386. doi:10.1016/j.im.2004.01.007

Lee, K.-W., Tsai, M. T., \& Lanting, M. C. (2011). From marketplace to marketspace: Investigating the consumer switch to online banking. Electronic Commerce Research and Applications, 10(1), 115-125. doi:10.1016/j.elarap.2010.08.005

Lee, M. C. (2009). Factors influencing the adoption of internet banking: an integration of TAM and TPB with perceived risk and perceived benefit. Electronic Commerce Research and Applications, 8(3), 130-141. doi:10.1016/j.elerap.2008.11.006

Lowry, P. B., Gaskin, J., Twyman, N., Hammer, B., \& Roberts, T. (2012). Taking "Fun and Games" seriously: proposing the Hedonic-Motivation System Adoption Model (HMSAM). Journal of the Association for Information Systems, 14(11), 617-671. Retrieved from https://papers.ssrn.com/sol3/papers.cfm?abstract_id=2177442

Martins, C., Oliveira, T., \& Popovic, A. (2014). Understanding the internet banking adoption: a unified theory of acceptance and use of technology and perceived risk application. 
International Journal of Information Management, 34(1), 1-13.

doi:10.1016/j.ijinfomgt.2013.06.002

Mols, P. N. (1998). The behavioral consequences of PC banking. International Journal ok Bank Marketing, 16(5), 195-201. doi:10.1108/02652329810228190

Nerme, P., Stenstrom, C., Darefelt, N., \& Soilen, K. S. (2013). Usage of internet banking among PICBE | 360 different segments as an example of innovation-trust and information needs. Journ all of Internet Banking and Commerce, 18(2), 1-7. Retrieved from http://www.icommercecentral.com/open-access/usage-of-internet-bankingamong-different-segments-as-an-example-of-innovation-trust-and-informationneeds-1-7.php?aid $=38216$

Oruca, O. E., \& Tatar, C. (2017). An investigation of factors that affect internet banking usage based on structural equation model. Computers in Human Behavior, 66, 232-235. doi:10.1016/j.chb.2016.09.059

Thornton, J., \& White, L. (2001). Customer orientations and usage of financial distribution channels. Journal of Services Marketing, 15(3), 168-185. doi:10.1108/08876040110392461

Venkatesh, V., Morris, M. G., Gordon, D. B., \& Davis, F. D. (2003). User acceptance of information technology: toward a unified view. MIS Quarterly, 27(3), 425. doi: $10.2307 / 30036540$

Yee-Loong Chong, A., Ooi, K.-B., Lin, B., \& Tan, B.-I. (2010). Online banking adoption: an empirical analysis. International Journal of Bank Marketing, 28(4), 267-287. doi:10.1108/02652321011054963 